\title{
A first record of Amblyomma dissimile (Acari: Ixodidae) parasitizing the lizard Ameiva ameiva (Teiidae) in Brazil
}

\author{
Primeiro registro de Amblyomma dissimile (Acari: Ixodidae) \\ parasitando o lagarto Ameiva ameiva (Teiidae) no Brasil
}

Suzana Gomes Lopes ${ }^{1 *}$; Gilda Vasconcellos de Andrade'; Lívio Martins Costa-Júnior ${ }^{2}$

\begin{abstract}
${ }^{1}$ Laboratório de Herpetologia e Ecologia aplicada à Conservação, Departamento de Biologia,
Centro de Ciências Biológicas e da Saúde, Universidade Federal do Maranhão - UFMA

${ }^{2}$ Centro de Ciências Agrárias e Ambientais, Universidade Federal do Maranhão - UFMA
\end{abstract}

Received May 24, 2010

Accepted July 7, 2010

\begin{abstract}
A non-engorged adult female Amblyomma dissimile and two Amblyomma sp. larvae were found parasitizing the lizard Ameiva ameiva in the municipality of Chapadinha, State of Maranhão. This is the first record in the state of Maranhão and fills a gap in the distribution of $A$. dissimile in Brazil. The lizard $A$. ameiva represents a new host for A. dissimile, and also the first record of this tick species infesting lizards of the family Teiidae in Brazil.
\end{abstract}

Keywords: Amblyomma dissimile, tick, Teiidae, Ameiva ameiva, Brazil.

\section{Resumo}

Uma fêmea adulta não ingurgitada de Amblyomma dissimile e duas larvas de Amblyomma sp. foram encontradas parasitando o lagarto Ameiva ameiva no município de Chapadinha, Estado do Maranhão. Além de representar um novo registro para o Estado do Maranhão, esse trabalho preenche uma lacuna de distribuiçáo geográfica de $A$. dissimile no país. O lagarto $A$. ameiva representa um novo hospedeiro para $A$. dissimile, sendo também o primeiro registro dessa espécie de carrapato infestando lagartos da família Teiidae no Brasil.

Palavras-chave: Amblyomma dissimile, carrapato, Teiidae, Ameiva ameiva, Brasil.

Amblyomma dissimile Koch 1844 is an ectoparasite commonly found on amphibians and reptiles. This parasite is widely distributed across several countries in the Americas, including some states in Brazil (Acre, Amazonas, Pará, Roraima, Pernambuco, Mato Grosso do Sul, Mato Grosso, and São Paulo) (ARAGÁO, 1936; SCHUMAKER; BARROS, 1994; ONOFRIO, 2007; DANTAS-TORRES et al., 2008). Records of natural tick infestation of lizards in Brazil are rare because most published reports available in the literature on parasitism focus on either snakes or on laboratory experiments (SCHUMAKER; BARROS, 1994; FREITAS et al., 2004). At present, only two species of lizards have been reported to be infested by $A$. dissimile in Brazil, namely, adults from Iguana iguana (FREITAS et al., 2004) and nymphs from Tropidurus hispidus (DANTAS-TORRES et al., 2008).

The teiid lizard Ameiva ameiva is widely distributed in the Neotropics, occurring from Panama to central Brazil (SCHWARTZ; HENDERSON, 1991 apud SARTORIUS et al., 1999). This species

\footnotetext{
*Corresponding author: Suzana Gomes Lopes

Laboratório de Herpetologia e Ecologia aplicada à Conservaçáo,

Departamento de Biologia, Centro de Ciências Biológicas e da Saúde,

Universidade Federal do Maranhão - UFMA, Av. dos Portugueses, s/n,

Campus do Bacanga, CEP 65085-580, São Luis - MA, Brazil;

e-mail: suzanagms.lopes@gmail.com
}

of lizard inhabits areas ranging from the Amazonian rain forest to the savanna of Cerrado and the semi-arid region of Caatinga (VITT; COLLI, 1994). Even as a medium-sized lizard, it has fast movements and is an active forager that feeds on a variety of arthropods and vertebrates (VITT; COLLI, 1994). The objective of this study is to report the occurrence of $A$. dissimile parasitizing the lizard A. ameiva in the state of Maranhão, Northeastern Brazil.

A specimen of $A$. ameiva was collected in an area of Cerrado belonging to the Universidade Federal do Maranhão $\left(05^{\circ} 44^{\prime} \mathrm{S}\right.$ and $\left.43^{\circ} 10^{\prime} \mathrm{W}\right)$ in the municipality of Chapadinha, Maranhão. The lizard was visually examined for the presence of ectoparasites (Figure 1a). An engorged adult female tick and two larvae were found, collected manually and preserved in identified bottles containing $70 \%$ ethanol. The ticks were analyzed and identified with the aid of a stereomicroscope and according to the dichotomous keys of Aragão e Fonseca (1961) and Onofrio et al. (2006). The adult tick was identified as $A$. dissimile (Figure 1b) and the two larvae as Amblyomma sp.

Most of the studies on infestations of reptiles in Brazil concern the Amblyomma rotundatum, another parasite of "cold-blooded" animals that is well established in the country (ONOFRIO et al., 2006). This tick has been reported to be a parasite of $A$. ameiva (ONOFRIO, 2007), but data about the location were not reported. According to Pontes et al. (2009), data on A. dissimile 
and $A$. rotundatum in Brazil indicate that these two species may have a geographically sympatric distribution in the country. At present, the known geographical distribution of $A$. rotundatum in Brazil is broader than that of $A$. dissimile. Thus, further studies are needed to corroborate this idea. The municipality of Chapadinha is within the known range for $A$. dissimile in Brazil, but the collected specimen represents the first recorded occurrence in the state of Maranhão and fills a distribution gap (Figure 2). This is a report of $A$. ameiva as a new host for $A$. dissimile and is also the first record of this tick species infesting lizards of the family Teiidae in Brazil.

Infestations by larvae and nymphs of Amblyomma spp. have been reported in some species of Brazilian reptiles (PEREIRA et al., 2000; LABRUNA et al., 2002; DANTAS-TORRES et al., 2008, 2010), but the difficulty involved in identifying the immature stages of several species of Amblyomma found in Brazil has prevented a more precise identification.

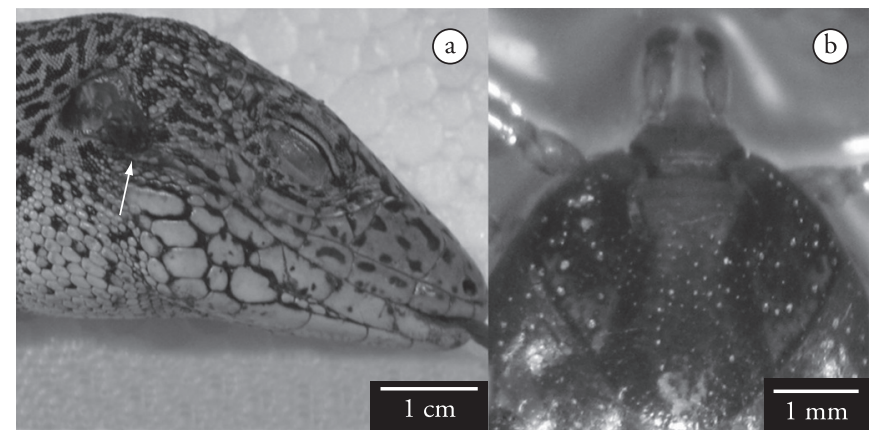

Figure 1. Adult female Amblyomma dissimile: a) Parasitizing an Ameiva ameiva lizard (white arrow); b) Ornated shield.

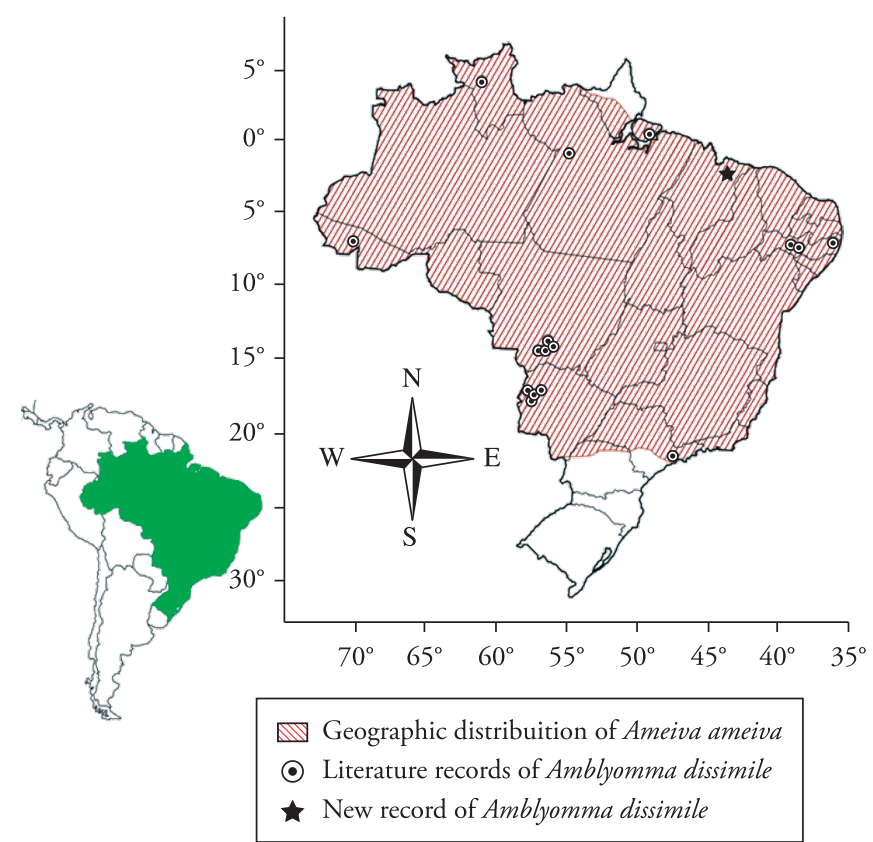

Figure 2. The geographic distribution of Ameiva ameiva and Amblyomma dissimile in Brazil. (Sources: ARAGÃO, 1936; ONOFRIO, 2007; DANTAS-TORRES et al., 2008; GBIF, 2009).
The lizard $A$. ameiva inhabits a range of ecosystems and is abundant in natural and anthropogenic areas (VITT; COLLI, 1994). Thus, it represents a potential host for ticks of the genus Amblyomma. Information on its geographical distribution and host-parasite relationship, in addition to contributing to the current knowledge of Brazilian tick fauna, provide insights for future research on the ecological and epidemiological infestations by $A$. dissimile of wild reptiles.

\section{Acknowledgements}

The authors would like to thank CAPES for the scholarship granted to S.G. Lopes as well as FAPEMA and CNPq for the scholarships granted to G.V. Andrade and L.M. Costa-Júnior. The authors also thank Etielle Barroso de Andrade for drawing the species distribution map.

\section{References}

ARAGÃO, H. B. Ixodidas brasileiros e de alguns países limítrofes. Memórias do Instituto Oswaldo Cruz, v. 31, n. 4, p. 759-843, 1936.

ARAGÃO, H. B.; FONSECA, F. Notas de Ixodologia. VIII. Lista e chaves para os representantes da fauna ixodológica brasileira. Memórias do Instituto Oswaldo Cruz, v. 59, n. 2, p. 115-130, 1961.

DANTAS-TORRES, F. et al. Ticks infesting amphibians and reptiles in Pernambuco, Northeastern Brazil. Revista Brasileira de Parasitologia Veterinária, v. 17, n. 4, p. 218-221, 2008.

DANTAS-TORRES, F. et al. Ticks on captive and free-living wild animals in northeastern Brazil. Experimental and Applied Acarology, v. 50, n. 2, p. 181-189, 2010.

FREITAS, L. H. T. et al. Experimental infestation with the immatures of Amblyomma dissimile Koch, 1844 (Acari: Ixodidae) on Tropidurus torquatus (Lacertilia: Iguanidae) and Oryctolagus cuniculus. Arquivo Brasileiro de Medicina Veterinária e Zootecnia, v. 56, n. 1, p. 126-129, 2004.

GLOBAL BIODIVERSITY INFORMATION FACILITY - GBIF. Species Ameiva ameiva Linnaeus, 1758. Disponível em: <http://data. gbif.org/species/13500252>. Acesso em: 16 jan. 2009.

LABRUNA, M. B. et al. Ticks (Acari: Ixodidae) on wilds animals from the Porto-Primavera Hydroelectric power station area, Brazil. Memórias do Instituto Oswaldo Cruz, v. 97, n. 8, p. 1133-1136, 2002.

ONOFRIO, V. C. et al. Comentários e chaves para as espécies do gênero Amblyomma. In: BARROS-BATTESTI, D. M.; ARZUA, M.; BECHARA, G. H. (Ed.). Carrapatos de importância médico-veterinária da Regiáo Neotropical: um guia ilustrado para identificaçáo de espécies. São Paulo: Vox/ICTTD-3/Butantan, 2006. p. 53-113.

ONOFRIO, V. C. Revisão do gênero Amblyomma Koch, 1844 (Acari: Ixodidae) no Brasil. 2007. 174 f. Tese (Doutorado em Ciências Veterinárias)-Universidade Federal Rural do Rio de Janeiro, Seropédica, 2007.

PEREIRA, M. C. et al. Ticks (Acari: Ixodidae) associated with wild animals in the Pantanal Region of Brazil. Journal of Medical Entomology, v. 37, n. 6, p. 979-983, 2000. 
PONTES, J. A. L. et al. Ecology of ticks in a taxocenosis of snakes from the Serra do Mendanha, Rio de Janeiro, Brazil, with new host records. Zoologia, v. 26, n. 2, p. 328-333, 2009.

SARTORIUS, S. S.; VITT, L. J.; COLLI, G. R. Use of naturally and antropogenically disturbed habitats in Amazonian rainforest by the teiid lizard Ameiva ameiva. Biological Conservation, v. 90, p. 91-101, 1999.
SCHUMAKER, T. T. S.; BARROS, D. M. Notes on the biology of Amblyomma dissimile Koch, 1844 (Acari: Ixodida) on Bufo marinus (Linnaeus, 1758) from Brazil. Memórias do Instituto Oswaldo Cruz, v. 89, n. 1, p. 29-31, 1994.

VITT, L. J.; COLLI, G. R. Geographical ecology of a Neotropical lizard: Ameiva ameiva (Teiidae) in Brazil. Canadian Journal of Zoology, v. 72, p. 1986-2008, 1994. 